\title{
インドネシア・ジャワ島の持続可能な森林保全をめざす 非木材林産物のサトウヤシ砂糖の生産工程調査と日本での商品化の試み
}

\author{
佐藤 輝 ${ }^{*)} \cdot$ 仲摩栄一郎 ${ }^{2)} \cdot$ 久野真希子 ${ }^{3)} \cdot$ 矢田 誠 ${ }^{4)}$
}

\section{Research on the production process of the palm sugar of Arenga pinnata as a non-timber forest product for sustainable forest conservation in Java, Indonesia, and a trial for its commercialization in Japan.}

Akira Sato ${ }^{1 *)}$, Eiichiro Nakama ${ }^{2)}$, Makiko Kuno ${ }^{3)}$ and Makoto Yata ${ }^{4)}$

\section{摘要}

持続的な森林保全にむけて重要な非木材林産物としてサトウヤシ（Arenga pinnata）砂糖をインドネ シアから日本に輸入するために, 現地の生産工程の品質管理状況, 生産者の生計向上効果, および日 本での商品化の可能性を調查した。ジャワ島のバンテン州および西ジャワ州においてサトウヤシ砂糖 は，熱による滅菌処理および塵・虫の混入防止を施しながら伝統的な道具と工程によって生産され， 生産者一世帯あたり月間 10,000 30,000 円相当の収入源となることが明らかとなった。加工業者への聞 き取り調查で得られた現地での卸売価格を考虑して, サトゥヤシ砂糖 $1 \mathrm{~kg}$ あたりの日本での販売価格 は約 2,000 円となった。

さらに日本でのこの砂糖の需要を増やす新たなビジネスモデルについてセミナー開催を通じて検討 したところ, 個人経営の洋菓子店において高価格の珍しい砂糖として使用することが有効だと判断し た。女子大学生 61 名による味覚試験においてサトウヤシ砂糖は甘味と酸味では黒糖と比べて弱く, 香 りでは燻蒸風味，黒みつ風味が強いと判定された。日本市場でこれを定着させるためには，これらの 味と香りを活用しつつ, 夾雑物（特に灰粒子）の低減・除去方法の確立と非木材林産物の意義を消費 者へ啓発することが必要と考えられた。

\section{Abstract}

In this study, with respect to importing the palm sugar of Arenga pinnata from Indonesia to Japan as an important non-timber forest product (NTFP) for sustainable forest conservation, we investigated the situation regarding quality management in the local production process, the income improvement effect on producers, and the possibility of its commercialization in Japan. In the Banteng and West Java provinces of Java Island, the producer's income per household was found to be the equivalent of 10,000-30,000 yen per month when using traditional tools and a heat sterilization process, and when taking measures to prevent dust and insects from getting into the sugar. In consideration of local wholesale prices, as determined by

1）フェリス女学院大学国際交流学部，＝245-8650 神奈川県横浜市泉区緑園 4-5-3

2）公益財団法人国際緑化推進センター， † 112-0004 東京都文京区後楽 1-7-12 林友ビル

3）プレマ株式会社， † 604-8331 京都府京都市中京区御供町 308

4）公益社団法人日本環境教育フォーラム， 116-0013 東京都荒川区西日暮里 5-38-5 日能研ビル

*連絡責任者：satoteru@ferris.ac.jp 
interviews with the processors, the selling price per kilogram in Japan was determined to be around 2,000 yen.

In addition to this research, a new business model to increase demand for this sugar in Japan was examined by holding a seminar. We concluded that the model would prove effective in marketing the product as a highpriced rare sugar in confectionery shops under private management. Arenga palm sugar is less sweet and also less sour than brown cane sugar, with a strong smoky and black honey flavor, according to a gustatory test conducted on 61 female university students. In order to promote its distribution in the Japanese market, it will be necessary to leverage this distinctive taste and flavor; establish methods to reduce and remove contaminants, especially ash particles; and raise the awareness of consumers with respect to the significance of NTFPs.

キーワード：インドネシア, 非木材林産物, ヤシ砂糖, 商品化, 味覚試験

Key words : Indonesia, non-timber forest products, palm sugar, commercialization, gustatory test

\section{1. はじめに}

発展途上国の農村の住民にとって, 森林と共生 しながら収入を得られる手段の一つとして, 森林内 で採取できる果物, 薬草, 香辛料等の非木材林産 物 (non-timber forest products, 以下では NTFPs と略す）の活用が国際的に注目されている。例え ば，東南アジアのさまざまな植物種の多様性と利 用技術（渡辺，2007）をはじめ, インドネシア・ スマトラ島での薬草や籐・竹のかご (Simbolon, 1994), ネパール (Bindu et al., 2013) やミャンマー (Senavirathna et al., 2014) での薬草, エクアドル のアクセサリー用ヤシの実 (Southgate et al., 1996)，スーダン, ナイジェリア，ペルーの環境保 全型農林業アグロフォレストリー（agroforestry, 以下 AF と略す) の経済的な利点 (Pearce and Mourato, 2004）などの研究事例がある。ただし, いずれも国内・地域内での利用・経済性が主要な 研究テーマである。一方, 公益財団法人国際緑化 推進センター（以下, JIFPRO と略す）では発展 途上国の「森林ビジネス」のデータベースとして, 日本との取引を念頭に置いた独自の調査に基づい て 22 品目の用途や経済効果をインターネット上 で公開している（JIFPRO，2016）。

インドネシアは世界第 3 位の熱帯林面積を有し ているものの, 1990 年代からのアブラヤシプラン テーションの開発等によって熱带林の純減少面積 が世界第 2 位となっている（賴, 2012）。熱帯林保 全のためにインドネシアでも 2000 年以降, $\mathrm{AF}$ へ
の関心の高まりとともに林業省を中心に林産物の 持続的な利用が推進されている。特に 2007 年, 林 業大臣決定 35 号「非木材林産物について」では, その生産を政府が強く推奨する NTFPs として 57 品目がリストアップされ，なかでもサトウヤシ (Arenga pinnata) の利用方法として, ヤシ砂糖, 果実の胚乳部分（コランカリン), 繊維の 3 つが挙 げられている。

公益社団法人日本環境教育フォーラム（以下， JEEF と略す）では, 2002 年から同国ジャワ島グ ヌン・ハリムン・サラク国立公園内外において NTFPs を取り入れた AF を支援し, とりわけサ卜 ウヤシ砂糖生産による住民の生計向上の可能性に 注目してきた（JEEF，2014）。これまでにヤシ砂 糖の研究に関しては, インドネシアのサトウヤシ, オウギヤシ (Borassus flabellifer)，ココヤシ（Cocos nucifera L.) 等の糖類等の組成分析（Tomomatsu et al., 1996 ; 仲宗根, 2004)，ミャンマーのオウギ ヤシ砂糖の生産状況調查（水野, 2012), インドネ シア中ジャワ州のココヤシ砂糖の生産状況調査 （Oikawa, 1998）があった。ヤシ砂糖は, 保存期間 が 2,3 年と長く, 長距離輸送も可能な産品であ る。

発展途上国の換金作物を公正な価格で先進国の 諸団体が輸入する貿易をフェアトレードという （例えば，ブラウン，1998）。インドネシアのサト ウヤシ砂糖の生産者を支援する新たな日本向けの フェアトレードの実現可能性を評価するために経 済的便益を把握することが不可欠であるが, 
Mokoginta（2015）のスラウェシ島で生計向上の 事例研究以外には, ほとんど見あたらなかった。 そこで本研究では, 現地の生産工程（特に先行研 究の少ない品質・衛生面), 流通・販売価格, 生産 者の生計向上の効果, さらには森林保全の状況に ついて, おもに聞き取り調査によって明らかにす ることを主要な目的とした。

またサトウヤシ砂糖の販路拡大のために, フェ リス女学院大学公認の学生団体エコキャンパス研 究会では横浜市内の洋菓子店やベーカリーの協力 を得て，この砂糖を使った商品化を企画してきた (佐藤ら，2015；佐藤，2017）。この一環として新 規の取扱店を探し出し, ヤシ砂糖製品の試作を依 頼し，これをセミナーにて一般の参加者に提供す るという過程を通してさらなる商品化を模索し た。セミナー参加者へのアンケート調査, および 試作品を調理した店主への聞き取り調査の結果も あわせて報告する。

このセミナーが契機となり，日本人にとって聞 き慣れないこの砂糖の香味・味覚をどのように消 費者に説明し, 宣伝するかの必要性を筆者らは実 感した。そこで, 日本市場において, サトウヤシ 砂糖と競合すると考えられる褐色の砂糖 (三温糖, てんさい糖，ココヤシ砂糖および黒糖）との違い を評価するために味覚試験をおこなった。これま でに食品や飲料の味覚試験の一例として, チーズ (荒井ら, 2010), 日本酒 (小林, 1989), ワイン (北野, 1997), 酢（木戸, 2006）の種類や銘柄を 比較する研究が存在した。砂糖を種類ごとに判定 した報告例では，精製された甘藷糖と甜菜糖の甘 味度の比較（飯田, 1954）や黒糖の生産地別の味 覚試験（大倉，2002）以外にはほとんど見あたら なかった。そこで,これらの評価項目を考虑して, サトウヤシ砂糖の特徵を簡易な味覚試験によって 明らかにすることを試みた。

\section{2. 材料と方法}

\section{1 サトウヤシの分布と特徵}

サトウヤシ (A. pinnata) は東南アジアを原産と するヤシ科クロツグ属の常緑高木で, インドネシ ア国内全域にわたって森林内に自生する在来種で ある。海抜 $0 \mathrm{~m}$ から $1,400 \mathrm{~m}$ において生育でき, 多目的利用が可能なことから各地で栽培も盛んで
あり，特に屋敷林や居住区に隣接する「里山」な どで多く見ることができる（佐野, 2006）。雌雄異 花同株, 1 回稔性を特徵とし, 15〜25 $\mathrm{m}$ ほどの樹 高まで育ち, 20〜25 年程度の樹齢を持つといわれ ている。年間を通じて花を咲かせ，発芽後 5 年ほ どで最初の花をつけ，雌花では年を追うごとに花 序を増やし，50 個ほどの果実が実る果房が 5〜10 房ほど垂れ下がる。果実の胚乳はデザートとして 生食される。また, 通常, 雄花の花序が出現する 際にこの基部を切断し, 連続的に滲出してくる花 序液が採集される。これがサトウヤシ砂糖の原料 である。

インドネシア・ジャワ島西部では, 燃焼効率に 優れた専用のかまどでサトウヤシの花序液が煮詰 められ, 砂糖が生産される。かまどの燃料は雑木 林の管理過程で発生する木材を有効活用してい る。このため, サトウヤシは森林生態系を破壊す ることなく地域社会に経済的便益をもたらす重要 かつ有望な NTFPであると言える。

\section{2 サトウヤシ砂糖の生産・加工工程}

インドネシア国内では, サトウヤシ砂糖, ココ ヤシ砂糖およびオウギヤシ砂糖のおもに 3 種類の 「ヤシ砂糖」が一般的に流通している。インドネシ ア料理には欠かせない調味料のケチャップ・マニ ス（甘口奨油）の原材料だけでなく，家庭では料 理や菓子づくり, コーヒー・紅茶の甘味料として 広く使用されている。現在, 日本国内におけるヤ シ砂糖の名称で取引のある商品のほとんどがココ ヤシを原料としている (考察 4.1.2 で詳述)。本研 究のサトウヤシから生産されるヤシ砂糖について は，これまでのところインドネシアから日本への 輸入実績はほぼないものと考えられ，日本向けの 品質の維持・向上を図るために生産現場での品質 管理の把握が必要である（JIFPRO, 2017）。そこ で，本調査ではサトウヤシ砂糖のインドネシア国 内生産量第 1 位の西ジャワ州, およびこれと隣接 するバンテン州を調查対象地とするとともに，日 本への輸入先行事例として，ココヤシ砂糖のおも な生産地である中ジャワ州, および隣接するジョ グジャカルタ特別州も調査対象地とした（図 1)。 それぞれの州のヤシ砂糖の生産者（農家）と加工 業者に対して, 生産工程, 卸売・販売価格, サプ 


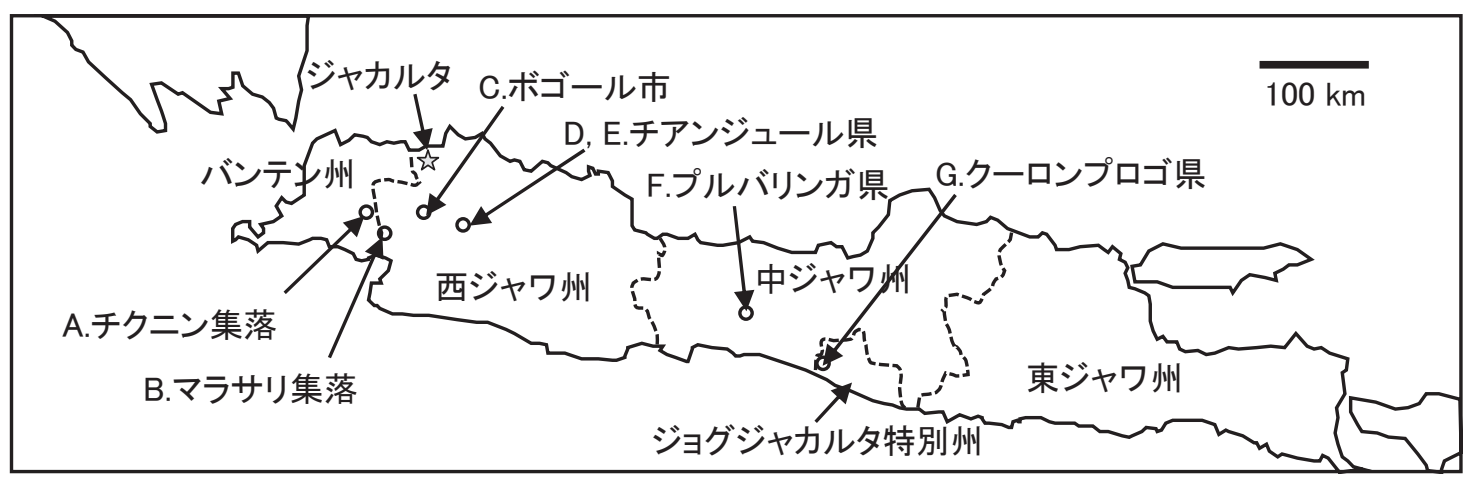

図 1 インドネシア・ジャワ島の調查対象地.

表 1 調査対象としたヤシ砂糖の生産者・加工業者の概要

\begin{tabular}{l|l|l|l|l}
\hline \multicolumn{1}{c|}{ 事業者 } & 砂糖の種類 & \multicolumn{1}{|c|}{ 所在地 } & 採取地 & \multicolumn{1}{|c}{ 調査年月日 } \\
\hline A 生産者 & サトウヤシ & バンテン州レバック県チクニン集落 & 保全林 & $2014.8 .25 \sim 27$ \\
B 生産者 & サトウヤシ & 西ジャワ州マラサリ村マラサリ集落 & 保全林 & $2015.8 .25 \sim 26$ \\
C 加工業者 & サトウヤシ & 西ジャワ州ボゴール市 & 保全林 & 2016.8 .28 \\
D 生産者 & サトウヤシ & 西ジャワ州チアンジュール県 & 民有林 & 2016.8 .29 \\
E 加工業者 & サトウヤシ & 西ジャワ州チアンジュール県 & 民有林 & 2016.8 .30 \\
F 加工業者 & ココヤシ & 中ジャワ州プルバリンガ県 & 民有林 & 2016.9 .2 \\
G 加工業者 & ココヤシ & ジョグジャカルタ特別州クーロンプロゴ県 & 民有林 & 2016.9 .1 \\
\hline
\end{tabular}

ライチェーンの現状と課題, および生産者の生計 向上への寄与等について聞き取り調査を実施し た。それぞれの調查対象者の概要を表 1 に示した。

インドネシアにおいて対象産品の生産はプラン テーション等による大規模集約的生産はなされて おらず，中山間地域の森林における小規模生産が 大多数を占めている。生産者は近隣コミュニティ 内においてグループや協同組合を設立することが 一般的である。したがって具体的な生産コスト・ 体制や加工技術，森林保全の状況，集荷 - 流通経 路等を把握するためには, 個々の生産者や加工業 者への聞き取り調査がもっとも正確な情報入手先 となる。

インドネシアの国土面積 1 億 9300 万haのうち, 約 65\%がインドネシア政府により国有の「森林区 域」として指定され，主な機能に応じて保全林 $(22 \%)$, 保安林 $(24 \%)$, 生産林 (54\%) の 3 つに 分類されている（インドネシア林業省, 2014）。こ れまでに森林資源の商業利用が認められていな
かった国立公園等の保全林において，2000 年以 降，一定の基準を満たすことでNTFPs の利用が 可能となった。特に「特別ゾーン」（林業大臣令 2006 年第 56 号「国立公園におけるゾーネーショ ン指針」) や「環境保全モデル村（インドネシア語 で Model Kampung Konservasi, 以下, MKK と略 す。)」などを制定することを通じて NTFPs 利用 が活発化している（JIFPRO，2017）。

一方，森林区域外の民有林におけるヤシ砂糖生 産は森林保全政策等の規制を受けないことから， 森林区域に比べ自由度が高く，その規模も大きい。 生産者は森林維持の義務を負わないことから森林 管理体制については各グループの自主的な取り決 めに委ねられている。インドネシア環境林業大臣 令 2015 年第 32 号では, このことを踏まえ，かつ， この方向を改善するための政策として，第三者に よる森林摚乱を防止し，伝統的な知見に基づいて 森林を維持しつつ生産活動を行う森林を「権利林」 として定めて, 支援する方向性を打ち出している。 
森林を保全しながら有効活用したい場合に法的に 権利林として登録されることによって, 有権利者 の便宜の向上を図る仕組みと言えるだろう。民有 地が権利林に認定されると基本的に(1)保全, (2)保 護, (3)生産のいずれかの機能を有する森林として 維持する義務が発生するため, アブラヤシプラン テーションのように森林と認められていない利用 は不可能となる。

\section{3 サトウヤシ砂糖の日本での商品化}

\subsection{1 商品化を模索したセミナー開催}

日本での商品化のために使用したサトウヤシ砂糖 は, 首都ジャカルタに本部が所在する Agenkultur と いう非営利活動法人（表 1 の E 加工業者）の販売 する商品名 Enau という粉末状の製品である。現 地での同団体からの購入価格は $1 \mathrm{~kg}$ あたり 400 円 ほどであった（100ルピア＝1 円として換算）。

サトウヤシ砂糖のさらなる普及を目的として, 2016 年 4 月 17 日（日） 13 時〜 16 時に,「熱帯林 と共生するヤシ砂糖生産の応援セミナー」と題し たイベントをエコキャンパス研究会の主催で開催 した（増田ら，2016）。また, JEEF，および自然 食品の小売・卸売・貿易業のプレマ株式会社が共 催した。定員を 20 名とし, 参加費は無料で, 対象 者を「個人経営の洋菓子店, ベーカリー, 健康食 品の関係者, 料理研究家, フェアトレードや環境 ビジネス等に関心のある消費者, マスコミ関係者」 と広報した。

同セミナーでは, サトウヤシ砂糖のさまざまな 試作品を参加者に試食してもらう時間も設けた。 サトウヤシ砂糖を使用した洋菓子やパンを出品し てくれる店舗を探すために横浜市内の計 7 店舗に 試作を 2016 年 2 月に依頼し, 各店にヤシ砂糖を 1 $\mathrm{kg}$ ずつ無償提供した。セミナー当日までに 5 店舗 から試作品を受けとった。参加者には, 試食の感 想を含め, 無記名のアンケート形式でセミナーに 対する評価・意見を募った。

\subsection{2 砂糖の味覚試験}

褐色の砂糖として三温糖 (日本精糖), てんさい 糖（ホクレン）, ココヤシ砂糖（上述の F 工場よ り提供), サトウヤシ砂糖 (上述の E工場の Enau), 黒糖（日新精糖）の 5 種類を用いて味覚試験を実
施した。 2016 年 12 月〜 17 年 4 月に計 4 回の機会 を設け, 合計 61 名 (18 歳から 22 歳の女子大学生) を被験者とした。甘味に対する嗜好では 19 歳から 21 歳（川染, 1968）や 16 歳から 50 歳 (Pangbon et al., 1957) で安定した結果が得られたという。被 験者には調查方法を説明するが，砂糖の種類は明 らかにせず，換気した部屋（室温 $20^{\circ} \mathrm{C}$ ）で適宜, 冷水を供しながら試食を実施した。無記名による アンケート形式で回答してもらった。

藤木·中村 (2011), 村山 (2008), 小林 (1989) の味覚表現も参考にしながら, 評価項目は 6 項目 とし，香りで 2 項目，味覚で 4 項目を設定した。 香りでは，口に入れる前の香り（上立ち香）と入 れた後の香り (含み香) を区別して，それぞれの 強弱を 5 点法で判定し, その特色を明確にするた めに，該当する用語を複数選択してもらった。一 方の味覚としては甘味, 酸味, うまみ, あとあじ のそれぞれの強弱について 5 点法で判定した。香 り・甘味の総合的な味わいを特徴づける評価項目 として, 該当する用語を複数選択可とした。総合 的なおいしさの度合いとしては, とてもおいしい (5 点), おいしい (4 点), ごく普通 (3 点), やや 難あり (2 点), かなり難あり（1 点）の中から 1 つを選択してもらった。

\section{3. 結果}

\section{1 サトウヤシ砂糖の生産・流通}

\subsection{1 生産工程とサプライチェーン}

サトウヤシの花序液を採取してから砂糖を得る までの生産者の品質管理項目としては, おおむね 以下を確認できた。

(1) 採液中…竹筒の開口部を植物の葉などで覆 い, 塵や虫の混入を防ぐ。

(2) 採液後…竹筒の開口部には火のついた薪を 挿入して, 燻蒸熱によって滅菌処理する。

(3) 加熱濃縮前…異物を除去するために花序液 を綿製のガーゼ等で濾過する。

(4) 加熱濃縮後…木枠に流し固形化させるか, 粉末状になるまで大鍋の中で擋拌する。

次に, 原料生産, 集荷, 包装, 販売のサプライ チェーンの概要に沿って, 調査の結果を記載する。 まず各過程のおもなステークホルダーとサトウヤ 


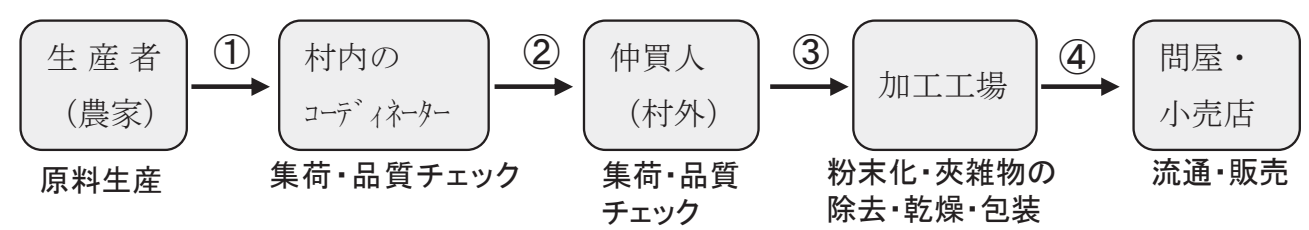

図 2 インドネシアのサトウヤシ砂糖の原料生産, 集荷, 包装, 販売のサプライチェーン概略図.

表 2 インドネシア国内の流通の各段階と日本国内のサトウヤシ砂糖の販売単価の概要

\begin{tabular}{|c|c|c|c|c|c|}
\hline \multirow{2}{*}{ 流通段階 } & \multicolumn{4}{|c|}{ インドネシア国内 } & \multirow{2}{*}{$\begin{array}{l}\text { 日本国内 } \\
\text { ウェブ販売 }\end{array}$} \\
\hline & 生産者 & 仲買人 & 加工工場 & 小売店 & \\
\hline $\begin{array}{c}\text { 販売単価 } \\
(1 \mathrm{~kg} \text { あたり) }\end{array}$ & 150 円 & 200 円 & 500 円 & 1,000 円 & 1,600 円〜2,000 円 \\
\hline
\end{tabular}

シ砂糖製品の流れを図 2 に示す。農家で生産され たサトウヤシ砂糖（粉末, 固形) は, 村内のコー ディネーター (1))，あるいは村外の仲買人 (2) によって集荷され, 加工工場に運ばれる（3)。地 理的に近い場合には農家が直接，加工工場に搬入 する場合もある。(1)〜 (3)の段階で, 製品の目視と 味覚によって品質のチェックがおこなわれる。加 工工場において夾雑物の除去や粉砕, 乾燥処理が 施され, $25 \mathrm{~g} \sim 5,000 \mathrm{~g}$ ごとに密閉包装され, 近隣 の問屋や小売店に納品される (4)。なお, 問屋に 納品された場合にはインドネシア全土に流通し, 1 割ほどは輸出用にも出荷される。

\section{1 .2 販売の価格・単価}

インドネシア国内（図 2 の各段階）および日本 国内における粉末状の販売単価の概要をまとめて 表 2 に示した。日本への輸入に際しては, 輸送コ ストに加えて, 砂糖には高い関税率 $(29.8 \%)$ が かけられていることから, 日本でのプレマ株式会 社からのサトウヤシ砂糖 $1 \mathrm{~kg}$ あたりの販売単価設 定は業務用 $(10 \mathrm{~kg}$ 単位, 2016 年 10 月に販売開 始）で 1,600 円, 個人消費者向け (250 g 単位, 2018 年から販売開始）で 2,000 円となった。なお, 日 本のマーケットでは, サトウヤシ砂糖とココヤシ 砂糖とはほとんど区別されていないが，インドネ シア国内では, 生産者, 加工工場, 流通（商品表 示）において明確に区別されていた。

\section{2 生産者の生計向上効果}

バンテン州レバック県チクニン集落

チクニン集落（図 1 , 表 1 の A) は, グヌン・八 リムン・サラク国立公園内に位置し, 同公園管理事 務所が進めるプログラムの一環として上述の MKK に 2010 年に指定され，AFを推進していた。 この MKK は, 以下の条件を満たすことによって指 定される住民参加型の環境保全活動である。(1)国 立公園内の「特別ゾーン」に認定されていること, (2)村内に住民グループを設立し，住民グループと 公園管理事務所との間で合意書 (memorandum of understandings，以下，MOU と略す）を締結す ること, (3)住民グループと公園職員の協働による 森林管理パトロールが行われること, (4)公園管理 事務所の要請にしたがって荒廃地での植林活動に 参加すること等である。住民側には活動に参加す ることが義務付けられている一方, 植林のための 苗木の供与を受けたり, 非木材林産物の採取等の 権利が与えられたりしていた。また林産物生産に おいては, 公園職員による生産技術向上トレーニ ング受講の機会や機材の供与の便宜が図られるな ど, 公園管理事務所と住民との win-win な関係の 構築をめざしていた。チクニン集落の全面積の 40\%に当たる約 138 ha が特別ゾーンであり, 水田 耕作や林地での NTFPs の採取が認められてい た。

この集落の約 1,000 戸のうち 30 戸がサトウヤシ 砂糖生産に従事していた。同集落の NTFPs の中 で最も生産量の多いのがサトウヤシ砂糖であり, 
集落全体では月平均で約 $14 \mathrm{t}$ が出荷されていると 推計された。成人男性一人あたり 1 日で最大 12 $\mathrm{kg}$ のヤシ砂糖を生産でき, 仲買人に約 100 円／ $\mathrm{kg}(100$ ルピア = 1 円として換算 $)$ で買い取って もらえるため, 収入は最大 1,200 円 $/$ 日と概算さ れた。砂糖生産は, 二期作で行われる水田耕作の 余暇時間を活用して行われるため, 砂糖生産に従 事できるのは 1 カ月のうち数日から 10 日間ほど だが, 仮に 8 日間としても月々 10,000 円ほどが得 られると推察された。これは, 同村の成人の平均 月収 10,000 円弱と比較しても大きな現金収入額 と言える。チクニン集落の調査で特筆すべきは, 住民が森林による生態系サービス (土砂災害防止, および水源・水質保全などの公益的機能，ならび にNTFPs の供給機能）をよく理解し，AFの実 践に大きなメリットを実感していた点だ。

西ジャワ州マラサリ村マラサリ集落

マラサリ集落（図1, 表 1 のB）において, 最 もヤシ砂糖生産量の多い家庭では, 1 本の竹筒 20 リットルの樹液を煮詰めると, 約 $1 \mathrm{~kg}$ のヤシ砂糖 ができ，これが 250 円 $/ \mathrm{kg}$ で集荷人に売れると いう。1 カ月の生産量は一人あたり $120 \mathrm{~kg}$ と概算 できたため,これによって平均で月間 30,000 円の 収入になっていた（副村長の月収が約 60,000 円）。

ただし現在，マラサリ村ではおもにヤシ砂糖生 産に従事しているのは年配者しかおらず，彼らが 体調不良等の理由によって採取できないとき以外 には，若年者はほとんど手伝わないとのことだ。 ヤシ砂糖生産は畜産や他の農作業に比べ, ヤシの 木に登って花序液を採取しなければならず, 非常 に重労働だからであるという。この後継者不足の 課題については, 同様にチクニン集落でも聞くこ とができた。

西ジャワ州スカブミ県

グヌン・ハリムン・サラク国立公園内の西ジャ ワ州スカブミ県シルナラサ村には, サトウヤシ砂 糖を採集し, 同州ボゴール市の加工業者（図 1, 表 1 のC）に納入する複数の生産者が存在する。彼 らは, 国立公園内の「伝統的利用ゾーン」におけ る 5 ha の森林からのサトウヤシ砂糖の採集に関 して同公園とのあいだに 2013 年 5 月に合意書 （MOU）を結んだ。国立公園内に居住する住民の 自立を支援する趣旨から，インドネシア政府から
の課税や環境林業省からの課徴金は一切ない。同 国立公園内のサトウヤシの自生密度は約 100 本／ ha であり, 2 集落 125 世帯のうち, 特に 25 世带 が生産を継続している。

一世帯あたり 1 日で平均 $5 \mathrm{~kg}$, 最大で $10 \mathrm{~kg}$ の サトウヤシ砂糖を生産でき（月間で平均 $100 \mathrm{~kg}$, 最大 $200 \mathrm{~kg}$ 生産), 村内のコーディネーターに よって粉末の状態で約 150 円 $/ \mathrm{kg}$ にて買い取っ てもらえるため, 一世帯あたり平均 15,000 円／月 の収入になると試算された。ここの生産者は, 他 にもクローブ, バナナなどを栽培しているが, サ トウヤシ砂糖生産が最も大きな収入源となるそう だ。

西ジャワ州チアンジュール県

西ジャワ州チアンジュール県シンダンカラ村 （図 1, 表 1 の）では, AF の実践農園として, 1 ha あたり約 100 本のサトウヤシの木が存在し, そ のうち 30 本から採液していた。サトウヤシの他 に, クローブ, コショウ, コーヒー, 果物類の木 本植物が配置され, トウモロコシ, キャッサバイ モ, マメ科の作物が植えられていた。

村のサトウヤシ砂糖事業リーダーによると, 出 荷先としては特定の仲買人や工場はなく, 時期に 応じて最も高価に買い取ってもらえるところを選 んでいるという。この村では, リーダーに集めら れた砂糖は, $1 \mathrm{~kg}$ あたり約 300 円で仲買人に買い 取ってもらうが, 加熱濃縮が不十分なために，と きどき水分が多くなり買い取りを断られることが ある。

なお，チアンジュール県産業局農業産業指導課 長によると, 県全体のサトウヤシ生産の最盛期は 1996 年だった。当時は, 県内の全 35 郡のうち 21 郡（県の南部に集中）に事業体が 12,400 登録され ており，県全体で年間 2,100 億ルピア (21 億円) 生産し, 1 日に $51 \mathrm{t}$ の生産キャパシティがあった。 現在は, 3 分の 2 ほどに産業規模が縮小しており， そのおもな要因としては, サトウヤシの木の老化, 後継者不足の 2 つがあった。

\section{3 加工工程での品質管理と課題}

西ジャワ州ボゴール市

ボゴール市の団体 LP5MP（村落住民経済支援 研究所）の代表ジュフリザル氏（47 歳, 男性）の 
運営する加工業者（図 1，表 1 の C) では，製品 のトレーサビリティを確保するためにサトウヤシ 砂糖の入ったプラスティック製の半透明コンテナ (約 40 リットル容量の衣装ケース) には，すべて 番号が記されていた。LP5MPでは生産者からの 受領（納品）のコンテナ番号・計量日時・重量・ 棚番号・責任者名の報告リストとともに，毎日の 工場内での各工程 (乾燥, 粉砕, 包装) のコンテ ナ番号・数量・作業時刻・責任者名の記録を残し ていた。

$200 \mathrm{~g}$ 入り袋の片面が透明なフィルム入り商品 では，酸化・吸湿などが徐々に起きるため賞味期 限は 2 年間と設定されていた（インドネシア政府 の基準と同様)。他社の例として，両面がアルミ フィルムの場合には賞味期限が 3 年間の商品も存 在した。

品質保証として商品の成分をほほ 3 カ月に一 度，外部に委託して分析していた。おもな分析項 目は, 含水率（結果は約 $2 \%$ ), 夾雑物としての灰 分 (2.5\% 前後), タンパク質量, 全脂肪分, カロ リー数, 糖分, ショ糖含量, ビタミン $\mathrm{B}_{2}$ 含量, ナ トリウム, カルシウム, 鉄, 重金属類 (鉛, カド ミウム, スズ, 水銀, 七素), 微生物数 (大腸菌, 糸状菌, 酵母) 等であり, これまで特に問題は検 出されていない。なお，ジョグジャカル夕特別州 クーロンプロゴ県のココヤシ砂糖を扱う加工業者 （図 1, 表 1 の G）でも成分分析の結果を公表して いたが，測定項目は簡易なものだった（含水率 $(1.1 \%)$, 灰分 $(2.3 \%)$, 全脂肪分, カロリー数, 糖分, ショ糖含量, タンパク質量, 飽和脂肪, 卜 ランス脂肪)。

ただし、ジュフリザル氏の指摘する問題点とし て，竹筒の破片が砂糖にときどき混入しているこ とがあげられた。また, 花序液の濃縮段階では薪 の火を使っているため, 飛散する細かい灰の粒子 が混入する。この灰分は, ヤシ砂糖の重量の $3 \%$ 以下であればインドネシアの食品衛生基準を満た すことになっており，LP5MPの商品では上述の とおり $2 \%$ 台だった。

西ジャワ州チアンジュール県

非営利活動法人 Agenkultur が運営するチアン ジュール県の加工業者（図 1, 表 1 の E) では, 代 表のリズキー氏（29歳，男性）が 2012 年に村民
らとの共同出資によってサトウヤシ砂糖の加工工 場を立ち上げた。生産農家 300 軒ほどから, すべ て固形としてサトウヤシ砂糖を直接, 工場まで納 品してもらっていた。固形のほうが, その後の再 加熱・夾雑物の除去・粉末化を経て, 最終的な製 品の品質が安定化するためである。この工場では, 平均約 $2,000 \mathrm{~kg} /$ 月を固形のサトウヤシ砂糖とし て集荷しており, 日本への輸出（現状では目標 10 $\mathrm{kg} /$ 月) の供給能力は十分に備えていた。本加工 業者は，固形 $1 \mathrm{~kg}$ あたりを雨季には 12,000 ルピ ア (120 円), 乾季には 17,000 ルピア（170円）で 生産者から買い取っていた。

加工工場では, 生産者から集めた固形状のサ卜 ウヤシ砂糖 15 個ほどを約 1 リットルの熱湯に溶か し, 100 番メッシュ(フィルターの目開き $0.15 \mathrm{~mm}$ ) のフィルターで濾過して夾雑物を除去する（写真 1)。この工程は, 中ジャワ州プルバリンガ県の加 工業者（図 1 , 表 1 の F), およびジョグジャカル 夕特別州クーロンプロゴ県の加工業者（図 1, 表 1 の G）のいずれもココヤシ砂糖の場合でも採用 されており，インドネシア国内に普及しつつある 有効な夾雑物の除去方法の一つと言える。

この濾過した液体をプロパンガスで煮詰めて, 粉末状になるまで木べらで擋找した後, さらに機 械で 10 番メッシュ（ふるいの目開き $1.7 \mathrm{~mm} ） の$ ふるい分けを施すことによって，焦げの少なく， 粒子の均質な最終製品が完成する。以上の一連の

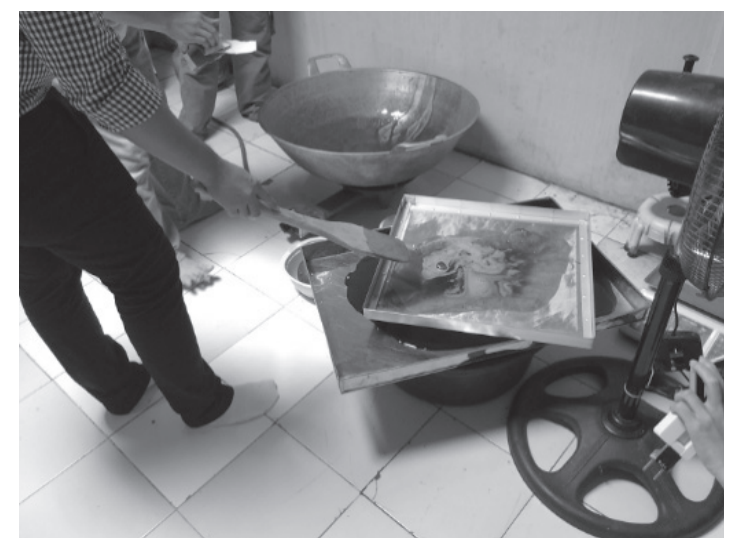

写真 1 チアンジュール県内の加工工場では 100 番メッシュのフィルターを使って, サト ウヤシ砂糖の濃縮液中の夾雑物を除去し ていた（2016 年 8 月 30 日，佐藤撮影）。 


\section{1. 生産農家から固形で受け入れる場合}

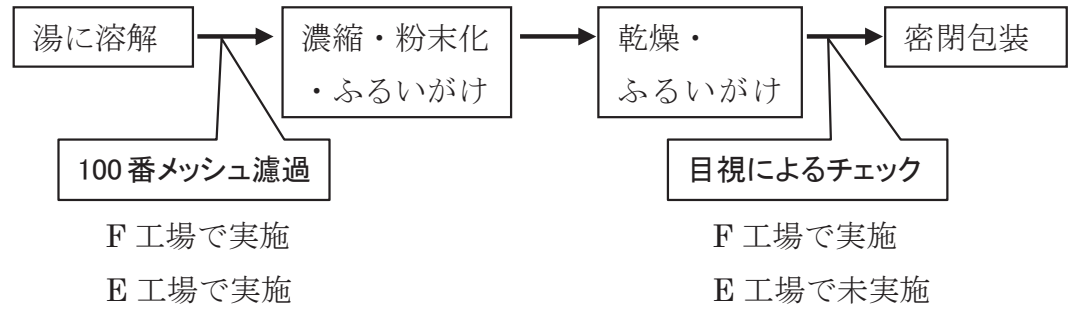

\section{2. 生産農家から粉末で受け入れる場合}

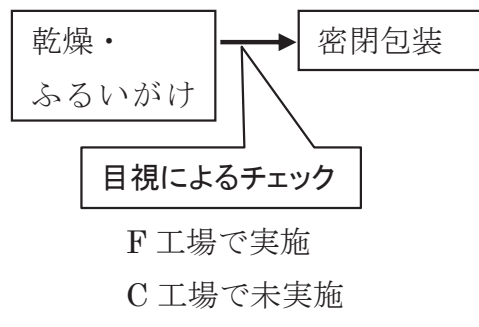

図 3 ヤシ砂糖の加工工場における, 1. 生産農家から固形で受け入れる場合, および2. 生産農家から粉末として受け入れる場合の各工程の概略と, 夾雑物除去に関する C 工場， E 工場，F工場の 100 番メッシュ濾過お よび目視チェックの実施の有無. F工場ではココヤシについて 1 と 2 の 両方, E工場ではサトウヤシについて 1 のみ, C工場ではサトウヤシに ついて 2 のみで操業していた.

工程については試行錯誤の上で独自に開発した。 中ジャワ州プルバリンガ県

インドネシア産サトウヤシ砂糖が日本の消費者 に受容され, 事業が継続するための最低限の品質 維持・向上のポイントとして, 夾雑物の除去があ る。この除去工程について, 調査した加工業者の うち，ココヤシ砂糖を扱う中ジャワ州プルバリン ガ県の F工場がもっとも品質管理レベルが高かっ た。すなわち, 図 3 の 1 番目のとおり，F工場で は, ココヤシ砂糖を生産農家から固形で受け入れ た場合には，粉末化のために溶解し，プロパンガ スの火で濃縮したあと, 100 番メッシュ（目開き $0.15 \mathrm{~mm})$ で濾過する段階までは E工場と同じ だった。ただし F 工場では，乾燥・ふるいがけの あと，従業員による目視のチェックを導入してい た (写真 2$) 。 こ の$ 作業は粉末で受け入れた場合に も実施されていた(図 3 の 2 番目)。ここで除去す る物質としては, 前述の灰や炭, あるいは昆虫類 の体の一部, ヒトの毛髪, 焦げた砂糖の粒子など だった。

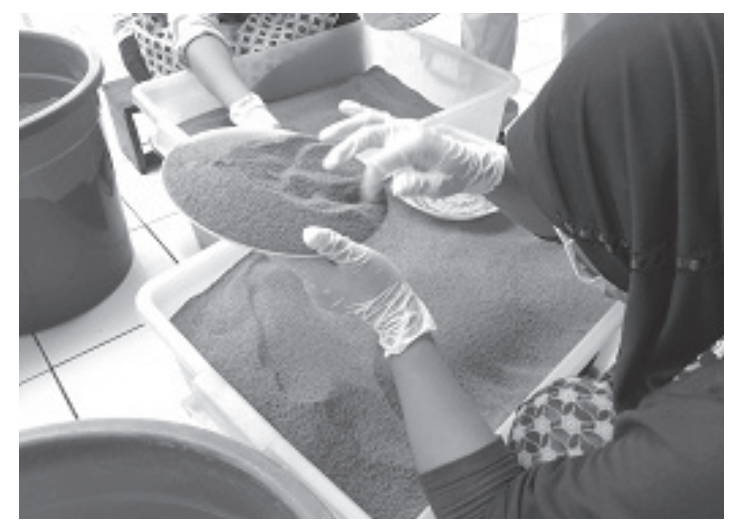

写真 2 包装の前に目視による夾雑物の除去工程 (中ジャワ州 F加工業者). 従業員は手袋, マスク，帽子を着用し，少量ずつヤシ砂 糖の粉末を製品コンテナ容器に広げる (2016 年 9 月 2 日, 佐藤撮影).

\section{4 サトウヤシ砂糖の日本での商品化}

\subsection{1 ヤシ砂糖の普及セミナー}

ヤシ砂糖の普及セミナーには, 駐日インドネシ ア大使館の林業部長，経済部長をはじめ, 23 名 


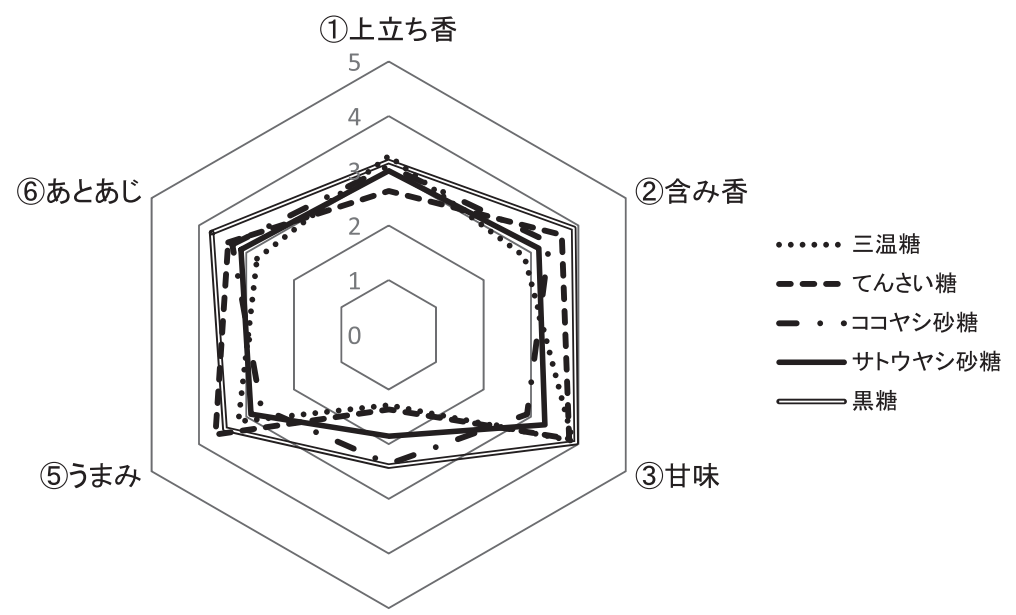

(4)酸味

図 4 砂糖 5 種類における香味・味覚の強弱の試験項目によるバランス評価比較 (被験者 61 名).

（女性 12 名, 男性 11 名）の参加があった。日本人 20 名にアンケート用紙を配布し 16 名から回答を 得た（回収率 $80 \%$ )。その結果, 参加者は 20 歳代 から 60 歳までの幅広い年齢層で構成され, 所属と して会社員が 6 名, 経営者 (エスニック料理の販 売や教室) が 3 名, 公務員 2 名等となった。

計 5 店舗のヤシ砂糖を使った試作品として, ベーカリー $\mathrm{H}$ 店の白あんデニッシュ, ベーカリー I 店のレーズンのヤシ砂糖ビスキーパン, レスト ラン $\mathrm{J}$ 店のクッキー 3 種（ココヤシ果肉, 紅茶, ナッツ類), ベーカリー K 店のマドレーヌ, フラ ンス料理店 L 店のマシュマロとアイスクリームが 試食に供された。セミナーでは，それぞれの商品 のコンセプトと販売想定価格が紹介され, 参加者 からいずれも良い評価を得た。特に L 店の両試作 品に対して「ヤシ砂糖の風味が最も感じられる逸 品」との好意的な感想が多かった。

セミナー全体に対する参加者のアンケート結果 としては,「とても良かった」が7名（回答者の 44\%)，「良かった」が5名（同 31\%）となり，「普 通だった」「「まり良くなかった」がいずれも 0 名, 無回答が 4 名（同 25\%）だった。アンケート 回答者のうち 12 名が「今後, ヤシ砂糖を使いた い」との選択肢を選んだが，2名からは安全性が 気になるので「どちらとも言えない」との回答だっ た。「使いたい」と回答した理由としては「おいし
かったから」が 5 名,「健康に良さそうだから」が 5 名,「支援のため」が 2 名,「日本には無いから」 が 2 名となった。

試作品を調理した店主らからは,「甘さの中に独 特の濃厚さとキャラメル風味があり, これを製品 として表現するのに苦労した」,「ヤシ砂糖がクッ キーの生地に溶けづらかった」といった特徴につ いてのコメントや,「上白糖よりも高価なので, パ ンの一般的な販売価格帯を超えてしまう」といっ たコスト面の懸念が示された。

\subsection{2 ヤシ砂糖の味覚試験}

砂糖 5 種類の味覚試験結果について, 香りとし てロに入れる前の(1)上立ち香と入れた後の(2)含み 香の強弱, また味覚として(3)甘味, (4)酸味, (5)う まみ, (6) ああじの強弱について被験者 61 名の平 均值の分布を図 4 に示す。サトウヤシ砂糖 (実線) は，特に競合する黒糖 (二重線) よりも全体的に $0.16 \sim 0.73$ 点の範囲で点数が低かったものの, 上 立ち香 (3.0), 含み香 (3.2), 甘味 (3.3), うまみ (2.9), あとあじ（3.1）ともに 3 点前後であり, 三 温糖 (点線), てんさい糖 (破線), ココヤシ砂糖 (一点破線) と比べても, どの評価項目ともに中間 的な点数だった。サトウヤシ砂糖の甘味 (3.3) は, 黒糖 (4.0), 三温糖 (3.9), てんさい糖（3.8）よ りも弱いと評価された。サトウヤシ砂糖の酸味 


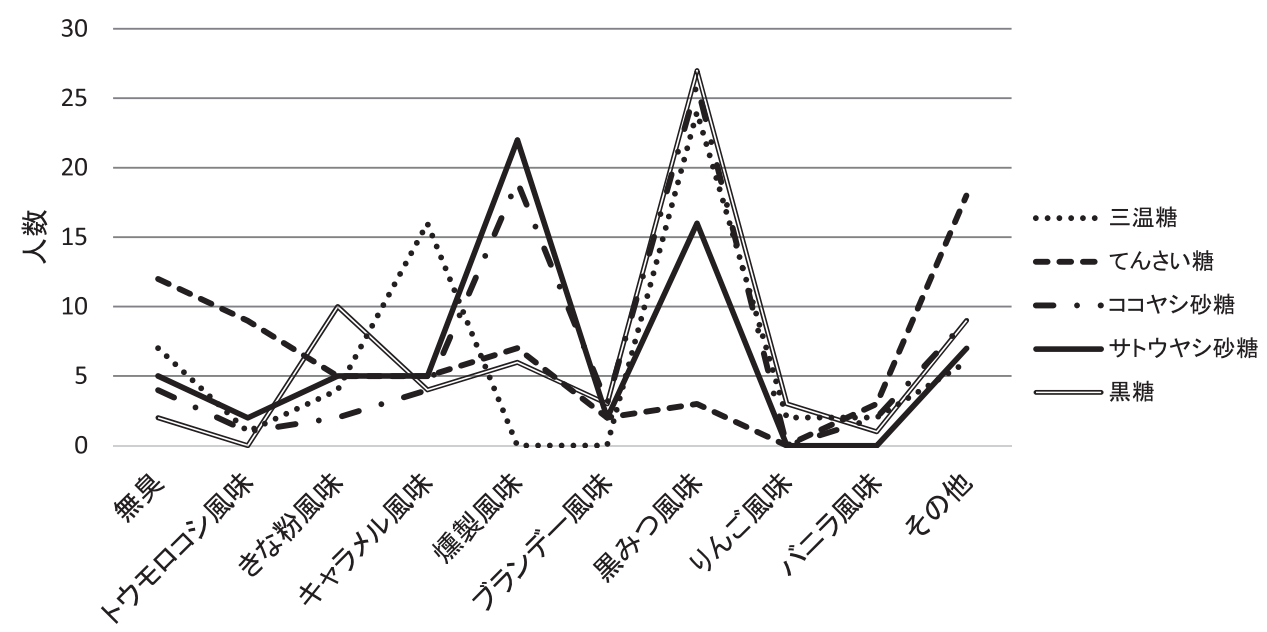

図 5 砂糖 5 種類の口に入れる前の香り（上立ち香）の味覚試験による比較.

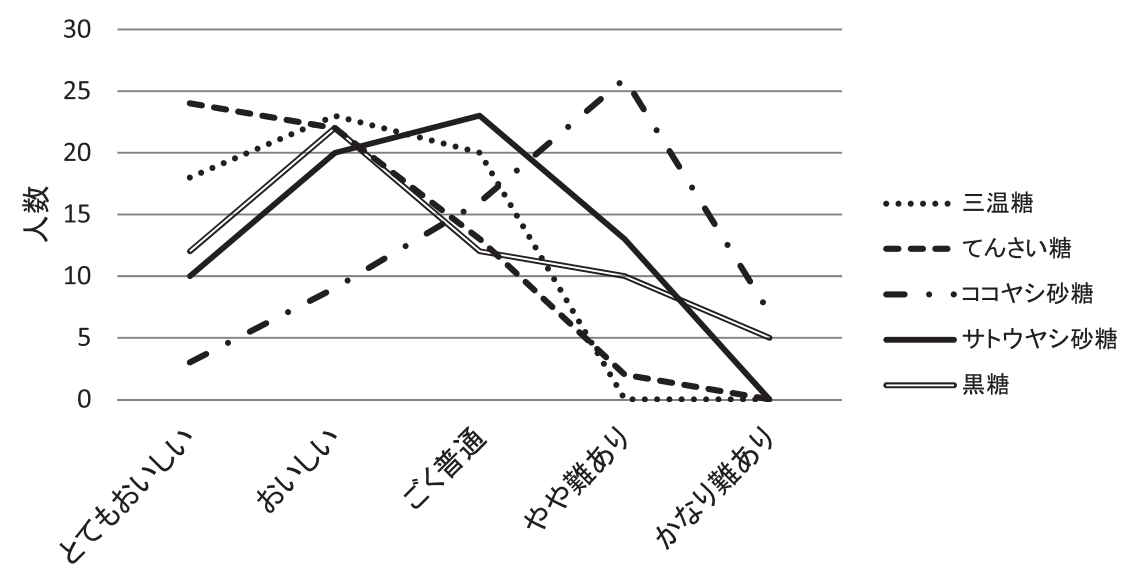

図 6 砂糖 5 種類の総合的な「おいしさ」の度合いの味覚試験による比較.

（1.9）は, 黒糖 (2.4), ココヤシ砂糖 (2.4) より も弱く, 三温糖 (1.3), てんさい糖 (1.4) よりも 強いとの評価だった。

香りの特徵としては, 図 5 の上立ち香のとおり, サトウヤシ砂糖 (実線)の「燻製風味」が 22 名と 最も多かった。また「黒みつ風味」という回答が 16 名となり, 黒糖 (二重線) の 27 名, ココヤシ 砂糖（一点破線）の 26 名, 三温糖（点線）の 24 名に次いで多かった。含み香でも同様の傾向を示 した。

香り・甘味の特徴を総合的に表現する言葉とし ては, サトウヤシ砂糖では, ココヤシ砂糖, 黒糖 とともに「重厚」,「コクがある」,「香ばしい」と いった選択肢が比較的多く選ばれた。
総合的なおいしさの度合いの評価として, サ卜 ウヤシ砂糖に対して「とてもおいしい」か「おい しい」と 61 名中 30 名が回答し，「ごく普通」と 23 名が回答した（図 6 の実線）。サトウヤシ砂糖 の平均点 3.4 は, てんさい糖 (4.1), 三温糖 (4.0) よりも低かったが, 黒糖（3.4）と同等だった。こ のおいしさの平均点は, 図 4 の (3)甘さの強弱の平 均点との相関係数が最も高く (0.83), $\mathrm{p}$ 值は 0.08 だった $(92 \%$ 水準では有意)。

\section{4. 考察}

\section{1 サトウヤシ砂糖の生産・加工}

\subsection{1 品質面の評価と課題}

サトウヤシの花序液を採取する竹筒の衛生管理 
面における燻蒸熱による滅菌, 塵・虫の混入防止 の方法（JIFPRO，2017）についても伝統的では あるものの（佐藤, 1959), これまでに日本の洋菓 子店やベーカリーの店主からは夾雑物や腐敗に対 するクレームは一切なく, また商品の購入者から の苦情・返品はいずれの店舗からも報告されてい ない。

ただし, 今後, 日本でサトウヤシ砂糖そのもの を一般消費者向けに広く販売し, 飲料や煮物等に 使用した場合には，灰分や焦げの粒子が容器の底 に沈殿するため，これに不安・疑義を呈する消費 者もいると予想される。味覚試験の自由記述欄で も指摘のあった燻製風味を軽減させたり, ザラザ ラ感をやわらげたりするためにも, 生産工程・加 工工程において，なるべく夾雑物を低減・除去す ることが望ましい。

今回の調查結果によれば, 夾雑物（灰分）の除 去が日本市場での普及にとって大きなポイントで あると考えられた。夾雑物の除去方法の理想は, 上白糖の製造工程と同様に, フィルタープレス機 （濾布を通す加圧滤過）を導入することだが, これ には数千万円の初期投資が必要であり, 現状で実 現は困難である。さしあたりの次善策として，ボ ゴール市のC工場に関しては生産農家においてサ トウヤシ砂糖を煮詰める直前に 100 番メッシュに よる濾過工程を追加する必要があるだろう。また, チアンジュール県の E工場では, サトウヤシ砂糖 の包装の直前に従業員による目視の工程を F工場 と同じように追加すれば, さらに品質は向上する と期待できる。このように生産農家や加工工場に おける技術指導や品質向上のための人材育成を今 後, 充実化させる必要がある。定期的に灰分の含 有率を検査することはもちろんのこと, 結果 3.3 で紹介した LP5MP の標準的な分析項目を他の加 工業者でも広く適用するなど, 日本向けに品質の 安定性を常に検証できることが望ましい。

\section{1 .2 価格面の評価と課題}

インターネットの通信販売を通じて日本で購入 できるヤシ砂糖商品を網羅的に検索調查したとこ ろ, 2016 年 8 月〜 12 月に閲覧できた 47 商品のう ち, ほとんどはココヤシ砂糖商品であり, それ以 外にはカンボジア産のパルミラヤシ砂糖が 1 商
品, 夕イ産のサトウヤシ砂糖が 1 商品のみであっ た。生産国としてはインドネシアが最も多く（24 商品), 次いでフィリピン (8 商品), カンボジア (5 商品), タイ (2 商品), インド (1 商品), 不明 (7 商品) となっていた。なお, 27 商品においては 血糖值の上がりにくい「低 GI 食品」であること をうたって消費者へ健康効果を宣伝していたが, この根拠となる文献・検査機関等は記載されてい なかった。販売の価格带としては, $1 \mathrm{~kg}$ あたり 2,000 円以上が 42 商品, 2,000 円以下が 5 商品のみ だった。

一般消費者向けの販売では, 価格が課題となっ てくる。本研究では, サトウヤシ砂糖 Enauの工 場からの出荷額は 400 円 $/ \mathrm{kg}$ だった（ただし, 值 引き交渉はおこなっていない)。これに, 船便の輸 送費 600 円 $/ \mathrm{kg}$ (500 kg 単位の一括輸送の場合), 関税率が $29.8 \%$ かか。さらには品質の不安定さ (一部に廃裹が出てしまう), および為替変動等の 一般的な輸入リスクがあるという現状では，日本 での販売価格は 2,000 円 $/ \mathrm{kg}$ とならざるを得な かった。しかしながら, 上記の他のヤシ砂糖商品 と比べれば, 比較的, 廉価と言えるのではないだ ろうか。今後, 品質が向上・安定化し, 日本での 消費量が増え, 1 回あたりの輸入量が増えていけ ば, 販売単価をさらに下げられる可能性がある。

\subsection{3 生計向上の効果}

ジャワ島における本研究のサトウヤシ砂糖生産 者一世帯あたりの収入は，月間 10,000～30,000 円 相当となることが明らかとなった。スラウェシ島 における Mokoginta (2015) の調查結果によれば, 専業の生産者では月間 20,000 円の収入と推定さ れ，この収入をもとにした支出のおもな使途は 5 つあり, 基礎的な衣食の充足, 家屋の整備費, 子 供の教育費, 家族・地域の行事, 医療費等であっ た。本研究のチクニン集落やマラサリ集落での聞 き取り調査においても，増収の使途として衣食住 の費用と子供（孫）の教育費が挙がっていた。サ トウヤシ砂糖の生産は, 中山間地域の経済・生活 環境にとって非常に重要な産業であり, 住民による 森林保全の動機にもつながっていた（Mokoginta, 2015; Lipton, 2015)。

ただし，ヤシ砂糖生産の現状として従事者の高 
齢化が進んでいた。おもな理由は, 若い男性にとっ ては重労働であり，高所での作業による危険性が 伴うこと，また「田舎っぽい」という印象が強い からだそうだ。収入額の上では同等のバイクタク シーの運転手（月収 9,000 円ほど）や建設業，工 場勤務（月収 13,000 円ほど），あるいは金の採掘 等を若者は選ぶ傾向がある。今後, 作業の安全性 や効率を高めるとともに，日本や諸外国への輸出 量を増やしていくことができれば，収入増によっ て若者がこの仕事に戻ってくる可能性があると C 工場の代表のジュフリザル氏は指摘していた。

\section{2 日本でのサトウヤシ砂糖の商品化}

\subsection{1 洋菓子店での販売例から見えた展望}

既にサトウヤシ砂糖商品をいくつか販売してい るラ・ベルデュール店（横浜市泉区）では有機産 物や品質の高い原料を使用しており，通常は，店 頭の商品表示（以下, POP と称す）では原料の情 報をほとんど表示せず，あくまでも「味で勝負」 していた。しかし，サトウヤシ砂糖については, 写真 3 のようにコクのある甘味の特徴やフェアト レードをめざす意義を揭出した。また，写真 3 の 下のスノーボールクッキー（12 個入りを 550 円で 販売）では，同様の高価格带の砂糖である和三盆 のクッキーとならべて陳列されるようになり，両 商品をセットで購入する顧客が多いという。風味 豊かで, 高価格の珍しい砂糖としてのアピールが 功を奏した好例と言えよう。

セミナー開催を通じた店主への聞き取り調查の 結果から，サトウヤシ砂糖のコスト面でも，ベー カリーよりも商品単価の高い洋菓子店やフランス 料理店のほうが継続的な販路として有望だと考え られた。前述の L 店では, 2017 年 2 月時点でヤシ 砂糖のメニュー（デザート）をときどき提供して いるという情報が得られた。

サトウヤシ砂糖商品の試作の依頼やセミナー参 加対象を個人経営の店舗にしぼった理由として は，店主自身が素材に対してこだわりを持ち，社 会貢献に積極的であり，かつ環境保全にも理解が ある場合，商品化に向けた意思決定が迅速である ことが挙げられる。同様の傾向がフェアトレード 商品を扱う小売店の特長でも提起されていた（安 延, 2012)。

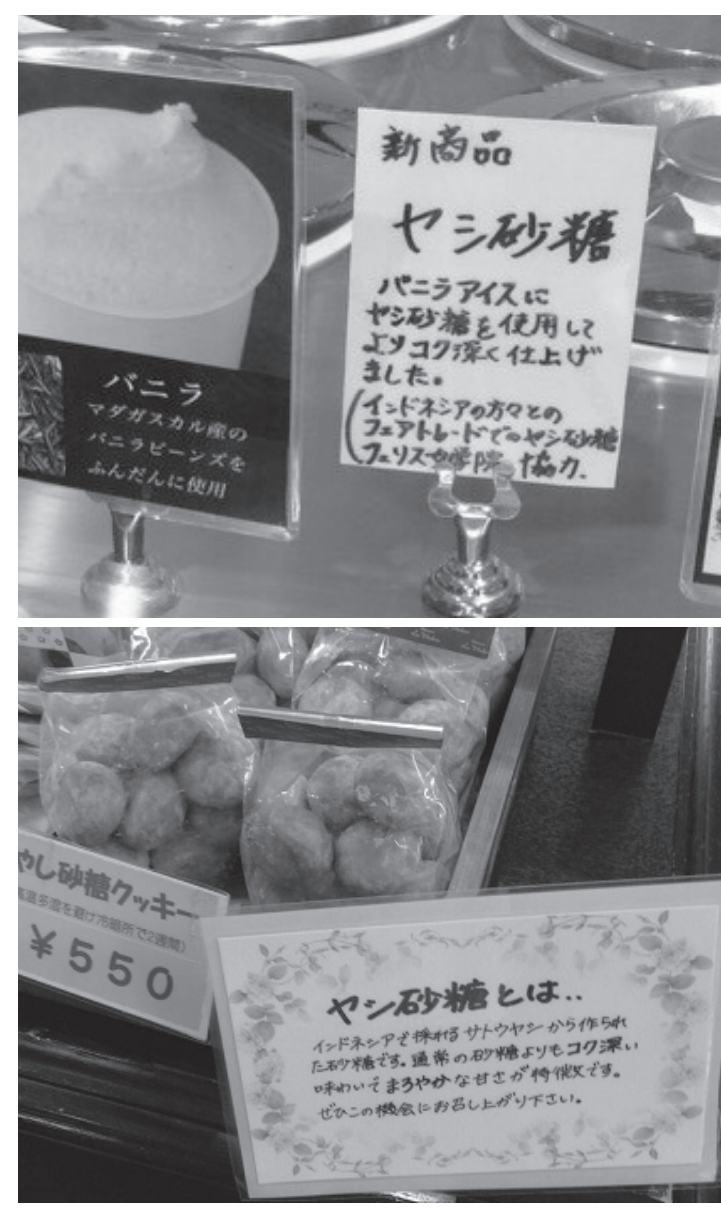

写真 3 横浜市内の洋菓子店ラ・ベルデュールで サトウヤシ砂糖商品の特徴や意義をア ピールする店内表示の一例. 上はジェ ラート，下はスノーボールクッキー。

\subsection{2 商品化の拡大に向けたノウハウ}

本研究では大学生の団体であるエコキャンパス 研究会がサトウヤシ砂糖の商品企画やセミナー開 催において大きな役割を果たしてきた。発展途上 国産品を販売する学生団体は全国に数多く存在す るが，そのほとんどは国際協力 $\mathrm{NGO}$ の取り扱う 既成の商品を学生たちで仕入れて販売する活動 だった（例えば，子島，2013）。学生が新たな商品 化を企画する活動はごく限られており，数少ない 先進事例としては，ラオス産コーヒーを日本国内 の焙煎業者を通じて商品化している東洋大学発の 学生団体ドリプロがあった（箕曲, 2015）。学生に よる企業との直接交渉や現地へのスタディーツ アー・調査の実施といったノウハウは, 同研究会 
とドリプロで共通しており, 学生団体が主体的な 活動をめざす上で重要な手法であると考えられ た。ただし, ドリプロでは, 取扱店内の POP を学 生自身が制作したり，インターネット上の学生団 体の SNS 等を活用して各店舗の広告や生産者の 状況を発信したりしており，同研究会にとって参 考になる活動が多く見られた。

味覚試験における特色の選択肢では, サトウヤ シ砂糖は「重厚」「コクがある」,「香ばしい」等 の項目が多く選ばれ，甘味が控えめと評価された。 サトウヤシ砂糖に多い乳酸とピログルタミン酸 （仲宗根, 2004）がそれぞれコクとさっぱり感のも とであると考えられた。また, サトウヤシ砂糖に は，未精製であるため多くのミネラル類が含まれ ており,さらには健康有効成分である葉酸, ポリ フェノール，イノシトール，およびナイアシン等 が多く含まれていた（JIFPRO，2017）。和菓子の イメージの強い黒糖とは一味違うサトウヤシ砂糖 の独特の味覚に加えて, 栄養面の特長や安全性も あわせて宣伝していく必要があるだろう。

日本の消費者（特に女性）はフェアトレード商 品購入の際に価格・品質・魅力を重視するとの報 告がある（渡辺, 2013）。サトウヤシ砂糖の場合, 「安さ」は該当しないものの,「おいしさ」,「健康」 といったメリットは十分にあると考えられるた め, これらの点では一般消費者にも広く受け入れ られるのではないだろうか。一方で「持続的な森 林保全のために周辺住民の生計向上にも役立って いる NTFP」という環境的な意義を宣伝すること によってグリーン購入やエシカル消費に理解のあ る顧客を長期的に獲得していくことにつながるか もしれない。

本研究では, 以上のようにサトウヤシ砂糖を初 めて日本に輸入し, 商品化の拡大にむけた知見を 蓄積することができた。今後, この手法を発展さ せていくことによって, 各店舗の「企業ブランド 価值」を向上させる利点も達成しつつ(大野, 2006; 畑山, 2013), 原材料の品質·調達や生産環境にま でさかのぼった正しい商品選びを顧客に促し（渡 未, 2012), 環境的・倫理的に配慮した商品が徐々 に社会に定着・普及していくことが期待できる。 さらに, 中山間地域の農家にとって木材伐採やア ブラヤシ産業と比べて，AF に従事する場合では
収入面や生活面にどのような特徴があるかについ て探究するために, 他の品目も含めた継続的な調 査が必要である。

\section{謝辞}

現地での調査, および洋菓子店等との連携に際 しては, フェリス女学院大学エコキャンパス研究 会の大学生, 特に星 万由子・櫻井美佑・石川 葵・ 増田瑛里沙 · 浮谷 菜・古屋理沙 $\cdot$ 武内萌香 $\cdot$ 高貴 小百合・荒関莉絵の諸氏による協力が不可欠で あった。中ジャワ州プルバリンガ県のココヤシ砂 糖の加工工場調査では, 富士蒲板株式会社・清水 政志氏のコーディネートに負うところが大きかっ た。林野庁「平成 28 年度 途上国持続可能な森林 経営推進事業 対象産品番号(3), 対象産品名 ヤシ 砂糖 (サトウヤシ)」からの助成を受けた。ここに 記して，心から感謝の意を表する。

\section{引用文献}

荒井威吉・玉木民子・海津夕希子（2010）「数種類 のチーズの官能評価における消費者の嗜好傾向 について」『新潟青陵大学短期大学部研究報告』 第 40 号, pp.27-35.

Bindu, S. et al. (2013) Potentiality of Income

Generation Through NTFP, Lap Lambert Academic Publishing.

ブラウン／マイケル・バラット（1998）『フェア・

トレード：公正なる貿易を求めて』青山 薰 · 市橋秀夫訳, 新評論.

藤木文乃·中村明朗（2011）「味とにおいの相互作

用」日下部裕子・和田有史編『味わいの認知科 学』勁草書房.

畑山要介 (2013)「フェアトレード運動の自由主義 的転換 - 慈善・開発・対抗の運動から $\mathrm{NPO}$ ・社 会的企業・CSRへー」『ソシオロジカル・ペー パーズ』第 22 巻, pp.23-50.

飯田廉雄（1954）『菓子・飴・砂糖』高陽書院.

インドネシア林業省 (2014) Buku Basis Data Spasial Kehutanan 2014.

川染節江（1968）「ココア・コーヒー・紅茶に用い る砂糖量と年令との関係」『家政学雑誌』第 19 巻第 1 号, pp.20-22.

木戸詔子 · 大野佳美 - 角田万里子 - 口羽章子 - 中 
原満子 (2006)「高齢者食事支援のための合わせ 酢の工夫と女子大生による官能評価」『日本調理 科学会誌』第 39 巻第 2 号, pp.140-147.

北野一好 (1997)「官能検査 3 - 官能評価用語とそ の技術的要因 -」『日本ブドウ・ワイン学会誌』 第 8 巻第 2 号, pp.98-104.

小林信也（1989）「日本酒の官能評価」『日本醉造 協会誌』第 84 巻第 12 号, pp.818-822.

子島 進 (2013)「ハートバザールのフェアトレード

活動一群馬県館林市における活動を中心に一」 『国際地域学研究(東洋大学国際地域学部紀要)』 第 16 号, pp.12-23.

増田瑛里沙 ·浮谷 菜 - 佐藤 輝 - 矢田 誠 - 田 儀耕司（2016）「インドネシアの熱帯林における 非木材林産物としてのヤシ砂糖の支援に関する 実証研究〜日本での販路拡大にむけた商品開発 企画～」『日本環境学会第 42 回研究発表会予稿 集』pp.94-95.

箕曲在弘（2015）「ラオス産フェアトレードコー ヒーの製造販売プロジェクトの活動経過」『国際 地域学研究 (東洋大学国際地域学部紀要)』第 18 号, pp.26-45.

水野明日香（2015）「グローバル化されるもの・さ れないものーミャンマーにおけるヤシ糖生産の 動向 $-」 『$ 亜細亜大学経済学紀要』第 39 巻第 $1 / 2$ 号, pp.43-66.

Mokoginta, M. M. (2015) Prospective use of palm (Arenga Pinnata Merr.) as raw material of sugar palm in the village of Moyag, Bolaang Mongondow, Indonesia, International Journal of Agriculture and Forestry, Vol. 5 (4), pp.240-244.

村山なおこ（2008）「菓子と砂糖のおいしい関係」 伊藤沉監修『砂糖の文化誌：日本人と砂糖』八 坂書房, pp.101-128.

仲宗根洋子 (2004)「インドネシア産ヤシ砂糖と甘 蔗糖の糖, 有機酸およびアミノ酸組成」『琉球大 学農学部学術報告』第 51 号, pp.127-130.

大野 敦 (2006)「国際開発政策におけるフェアト レードの可能性」『経済理論』第 42 巻第 4 号, pp.80-91.

Oikawa, Y. (1998) A preliminary survey on coconut-sugar-making homegardens in relation to fuel procurement in Banyumas, Central
Java, Tropics, Vol. 7 (3/4), pp.241-256.

大倉洋代 (2002)「南西諸島産黑糖の官能評価と製 造に関する研究」『日本食生活学会誌』第 12 巻 第 4 号, pp.342-347.

Pangbon, R. M., M. Simone, and T. A. Nikerson (1957) The influence of sugar in ice cream, Food Technology, Vol. 11, pp.679-682.

Pearce, D. and S. Mourato (2004) "The economic valuation of agroforestry's environmental services”, in Schroth, G. et al. (eds.) Agroforestry and Biodiversity Conservation in Tropical Landscapes, Island Press, pp.67-86.

賴＼cjkstart俊輔（2012）『インドネシアのアグリビジネス 改革』日本経済評論社.

佐野寿和（2006）「砂糖の生産（サトウカエデ, サ トウヤシ)」橋本 仁・高田明和編『砂糖の科 学』朝倉書店, p.21.

佐藤 輝 - 星 万由子 - 櫻井美佑 - 石川 葵 - 矢

田 誠・田儀耕司（2015）「インドネシアの環境 保全型農林業としてのヤシ砂糖生産への支援の 試み」『日本環境学会第 41 回研究発表会予稿集』 pp.32-33.

佐藤 輝（2017）「大学生による熱帯林保全のため のヤシ砂糖生産の支援活動」森林環境研究会編

著『森林環境 2017』森林文化協会, pp.156-165. 佐藤 孝（1959）「サトウヤシとヤシ砂糖，ヤシ 酒」『熱帯農業』第 3 巻第 1 号, pp.6-10.

Seravirathna, S. N., H. Withi, and T. Fujino (2014) Community knowledge and attitude towards regional developmental requirements in remote townships of Chin state, Myanmar - A questionnaire on sustainability and subsistence to overexploitation of natural resources -, International Journal of Human Culture Studies, No.24. pp.25-38.

Simbolon, H. (1994) Ethnobotany of people around the Dolok Sibual-buali Natural Reserve Area, North Sumatra, Indonesia, Tropics, Vol. 4 (1), pp.69-78.

Southgate, D., M. Coles-Ritchie, and P. SalazarCanelos (1996) "Can tropical forests be saved by harvesting non-timber products?: A case study for Ecuador", in Adamowicz, W. L. et al. 
(eds.) Forestry, Economics and the Environment, CAB International, pp.68-80.

Tomomatsu, A., T. Itoh, C. H. Wijaya, Z.

Nasution, J. Kumendong, and A. Matsuyama (1996) Chemical constituents of sugarcontaining sap and brown sugar from palm in Indonesia, Japanese Journal of Tropical Agriculture, Vol. 40 (4), pp.175-181.

渡辺弘之 (2007)『熱带林の恵み』京都大学学術出 版会.

渡辺龍也（2013）「フェアトレードと倫理的消費

(1) - 全国調査が明らかにするその動向 -」『現

代法学: 東京経済大学現代法学会誌』第 25 巻, pp.135-174.

渡未 絢 (2012)「フェアトレードの可能性 - 環境

保全と生活向上に寄与する環境配慮型活動を通

じて -」『横浜国際社会科学研究』第 16 巻第 6 号, pp.87-101.

安延久美（2012）「「提携型」フェアトレード小売
店の現状と課題」『農村生活研究』第 55 巻第 1 ・ 2 合併号, pp.13-23.

Lipton, C. (2015) The value of Sugar palm in Indonesia, National Geographic のウェブサイ ト http://energyblog.nationalgeographic. com/2015/03/18/the-value-of-sugar-palm-inindonesia/, 2017 年 12 月 12 日閲覧.

JEEF（2014）ヤシ砂糖加工品生産支援による人と 自然の共生プロジェクト http://www.jeef.or.jp/ activities/indonesia/, 2017 年 12 月 12 日閲覧.

JIFPRO (2016) BFPRO (途上国森林ビジネスデー タベース）https://jifpro.or.jp/bfpro/, 2017 年 12 月 12 日閲覧

JIFPRO（2017）BFPRO サトウヤシ砂糖（インド ネシア）https://jifpro.or.jp/bfpro/wp-content/ uploads/2017/05/business-model_Sugar-palm. pdf, 2017 年 12 月 12 日閲覧.

(2018 年 1 月 15 日受付, 2018 年 8 月 21 日受理)

\section{「ていねいに」そして「しっかりと」}

歴代の大臣をみわたすと，政策を語れる人は 限定される。環境に見識のない大臣はもとより， 憲法を知らない大臣，教育に情熱のない大臣な ど，よくもまあこんな人を集めたものだ。大臣 がこうであるから陣笠の国会議員はもっと寒々 しい。われわれにできることはせいぜい当選さ せたことへの反省であろうか。

国会議員一人に数千万円の税金が毎年流し込 まれていることを考えると，まじめな納税者と して腹が立つ。見識ある大臣や議員がいないな ら, せめて議員定数を減らして, 税金の有効利 用はわれわれが決めよう。などと，てをこまね いているうちに，あろうことか一票の格差是正

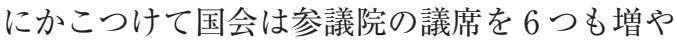
してしまった。

安倍首相の好みの言葉は「ていねいに」と 「しっかりと」である。彼はこれらの言葉で議論 をはぐらかし, 政策があるかのように暗示する。
たとえば,「ていねいに」説明しても無策は無 策，違法は違法。それなのに，首相はていねい な説明が足りないためとはぐらかして,「しっか りと」した政策があるかのように暗示している。 未だ「道半ば」であるから, 評価は「後半」を みてからとはぐらかし,「後半」でしっかりとし た成果が期待できるかのように暗示している。 加計学園の認可では,「規制」の意義をはぐらか して、「岩盤に穴」がさも功績のように暗示して いる。また，「ない」のに「ある」「できない」 のに「できる」かのように暗示する。たとえば, ギャンブル依存症をさけるために,「カジノ」へ の参加回数は制限するという。これも「できな い」のに「できる」かのような暗示である。

安倍首相は三選をめざしているようである。 「ていねいに」はぐらかして, 政策があるかのよ うに「しっかりと」暗示しつづけるのであろう。 彼の逃げ切りをどう阻止すべきか。

瀬戸昌之（元・東京農工大学） 